\title{
LABOR MARKET REGULATION AND THE LEGAL SYSTEM
}

\author{
CARSTEN HEFEKER \\ MichaEL NEUGART
}

CESIFO WORKING PAPER NO. 2041

CATEGORY 4: LABOUR MARKETS

JULY 2007

An electronic version of the paper may be downloaded

- from the SSRN website:

- from the RePEc website:

www.SSRN.com

- from the CESifo website:

www.RePEc.org

www.CESifo-group.de 


\title{
LABOR MARKET REGULATION AND THE LEGAL SYSTEM
}

\begin{abstract}
When enacting labor market regulation governments face courts that interpret and implement the legal code. We show that the incentives for governments for labor market reform increase with the uncertainty that is involved in the implementation of legal codes through courts. Given that judges have more discretion in common as opposed to civil law systems more reform activity as a response to crises should be observed in the former system. This finding is backed by evidence from a panel of OECD countries.
\end{abstract}

JEL Code: D78, K31.

Keywords: labor market regulation, labor courts, uncertainty, unemployment.

\author{
Carsten Hefeker \\ University of Siegen \\ Department of Economics \\ Hölderlinstr. 3 \\ 57076 Siegen \\ Germany \\ carsten.hefeker@uni-siegen.de
}

\author{
Michael Neugart \\ WZB \\ Social Science Research Center \\ Reichpietschufer 50 \\ 10785 Berlin \\ Germany \\ neugart@wz-berlin.de
}

June 5, 2007

For helpful comments we thank Helge Berger, Laszlo Goerke, Hans Peter Grüner and participants to presentations in Amsterdam and Berlin. 


\section{Introduction}

Although there is a widespread consensus among professional economists and international organizations that one of the major contributors to unemployment in developed economies is the (excessive) regulation of labor markets, countries differ to a considerable degree concerning the level of labor market regulation despite high rates of unemployment (OECD (1994) and OECD (2004)). This, inter alia, might reflect different social traditions, such as the Nordic, the European or Anglo-american "model", or the varying strength and influence of interest groups such as labor unions (for surveys, see Blanchard (2006), or Berger and Danninger (2006)). But countries not only differ with respect to the level of regulation, they also differ with respect to the specificity of regulation. Very often labor market regulation is put into legal code only in quite general terms. This is particularly the case in legal systems with a common law system, as opposed to those countries with a civil law origin, which leave it to the courts to interpret general rules and to adapt them to specific cases (see von Mehren and Gordley (1957)).

In this paper, we relate differences in countries' legal systems with governments' incentives to change labor market regulation. We develop and test a theoretical model to show that governments have a larger interest in reforming the labor market if they are confronted with a court system that has more discretion in interpreting the legal code. Intuitively this result stems from the fact that a government is more willing to take the political costs of deregulation if it can be less sure that the legal system enforces the legal code in an employment friendly way. Contrarily, if there is less uncertainty about the courts' interpretation of the law the government is less willing to pursue costly reforms and relies instead on employment friendly court decisions. Leaving it to the court to take the necessary steps, there is no need for the government to take the blame for unpopular policy measures itself. In addition to formally deriving our results in a simple game-theoretic model, we present empirical evidence to support our theoretical results.

Our argument touches on several strands in the literature. Since our main focus is the governments' incentives to reform labor market, our ap- 
proach is closely related to the growing literature on the political economy of economic policy reform. ${ }^{1}$ In this strand, various arguments have been developed that try to explain the (non)occurrence of economic reform under uncertainty. Relating to earlier work on the influence of interest groups (see Olson (1965)), war of attrition models explain delays in economic reform by arguing that uncertainty about the distribution of adjustment costs is an obstacle to welfare increasing reforms (Alesina and Drazen (1991)). Also, uncertainty about the benefits of a policy change can obstruct efforts. Again, welfare improving reforms may be voted down if the decisive voter is uncertain about his individual benefit from reform (Fernandez and Rodrik (1991)). Policy changes that would increase overall welfare may also fail because of the costly acquisition of necessary information which groups of society the government should compensate for losses due to policy reform (Grüner (2002)). Focussing on the interaction between a government and a central bank in a game-theoretic setup closely related to ours, Sibert and Sutherland (2000), Calmfors (2001), Hefeker (2001) or Neugart (2002) study the incentives of governments to reform labor markets as a consequence to a change in the monetary regime. In particular, Hefeker (2006) argues that more uncertainty about the central bank's reaction function can increase the incentives of governments to implement labor market reforms.

We add to this existing literature by explicitly taking into account the legal system as an additional player because in our view too little attention has been paid to the active role that the court system may play in the context of policy reform. This is particularly true in the field of labor market regulation where an increasing body of evidence suggests that courts have considerable leeway in interpreting the legal code which, in turn, has repercussions on the performance of labor markets. In the U.S., for instance, the tremendous increase in the share of temporary agency work has been attributed to the erosion of the employment-at-will doctrine through court rulings (Autor (2003)). There is also evidence for Italy that labor courts increasingly advocate in the interests of employees if the labor market is depressed (Ichino

\footnotetext{
${ }^{1}$ There are excellent surveys on the political economy of reform provided by Roland (2002) or Drazen (2000).
} 
et al. (2003)). For Germany, Berger and Neugart (2006) find evidence for a nomination bias in court rulings, that is, the share of settlements reached at each stage of the legal process and the propensity to appeal systematically varies with the political color of the government that nominated the judges. Furthermore, they present evidence that the number of cases filed to labor courts increases unemployment significantly.

Finally, we relate to the literature on the role of the legal origin for regulatory action (e.g. La Porta et al. (1998), Djankov et al. (2002), Djankov et al. (2003), La Porta et al. (2004), and Botero et al. (2005)). There, legal origin is classified either as civil or common law with the distinguishing feature that common law systems exhibit more judicial discretion. According to this approach, one should observe different institutional technologies depending on the legal tradition of countries; while common law countries depend more on markets and contracts, civil law countries depend more on regulation. We use indices developed to test those theories of legal origin to distinguish common from civil law countries in our empirical analysis as a proxy for the uncertainty governments face with respect to what the legal system will do in response to its policies. The underlying hypothesis is that court behavior is less predictable in common law countries which can therefore be characterized as creating more uncertainty for governments, inducing less stringent labor market regulation.

\section{The model}

Our model consists of two players, the government $(G)$ and the legal system $(C)$ which comprises all labor courts. ${ }^{2}$ We assume the government is Stackelberg-leader vis à vis labor courts (see figure 1), taking into account the expected reaction function of the court. First, the government makes its policy choice $\theta$ concerning the level of labor market regulation. Taken this as given, courts then decide whether and to what degree to confirm, change or enforce the legal code. The labor court's level of regulation is denoted by

\footnotetext{
${ }^{2}$ We thus abstract from potential complications of non-coordinated behavior or conflicts among individual courts.
} 


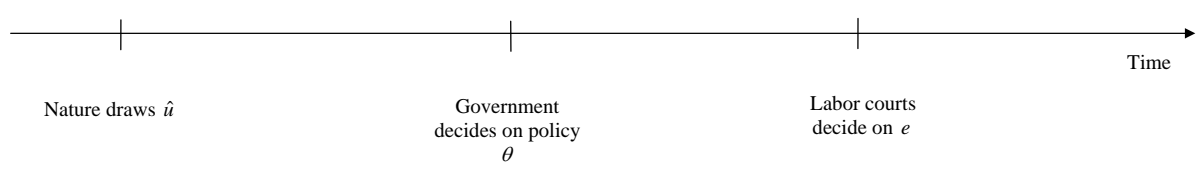

Figure 1: Sequence of events

$e$. Since the model is solved by backward induction, we begin by deriving the courts policy before turning to the government's policy choice. First, however, we describe the economy and the objective functions of the players.

\subsection{The economy}

Unemployment is given as

$$
u=\widehat{u}+\theta+e
$$

where $\widehat{u}$ refers to the non-regulation level of unemployment in the economy that is exogenous to government policy and court decision. This level may also reflect cyclical developments, changes in wages, changes in domestic or foreign demand for domestically produced goods (for instance due to exchange rate developments), or technological developments in the economy with employment friendly technological developments lowering $\widehat{u}$ and vice versa.

$\theta$ and $e$ are the regulation levels set by the government and the labor courts, respectively. $\theta$ could reflect, for instance, an increase in hiring or firing costs, the implementation of minimum wage laws, benefit systems or other actions by the government that increase unemployment. ${ }^{3}$ The model is very simple in the sense that we only look at unemployment and assume

\footnotetext{
${ }^{3}$ We do not enter a discussion here why governments regulate labor markets. Apart from protecting workers, this is most likely due to political economy considerations (Saint-Paul (2000)).
} 
that any regulation will increase unemployment. ${ }^{4}$ This is obviously a very strong simplification of the labor market. Likewise, we postulate that any deregulation will lead to more employment. Deviations of $e$ from $\theta$ reflect the influence of labor courts, which might increase $e>\theta$, decrease $e<\theta$, or simply confirm government policy in $\operatorname{court} \theta=e$.

\section{$2.2 \quad$ Preferences}

The government's objective function (a loss function) is given as

$$
V^{G}=E\left[u^{2}+c(\theta-\bar{\theta})^{2}\right] .
$$

with $E$ as the expectation operator. The government is interested in avoiding deviations of unemployment from zero, which is composed of exogenous developments $\widehat{u}$, and negatively affected by an increase in its policy variable regulation $\theta$. Moreover, the government is averse to deviations of labor market regulation from its preferred level $\bar{\theta}{ }^{5}$ This "target" level can be influenced by ideological leanings or the politically optimal level of regulation, resulting from a trade-off between the interests of different groups in society, such as labor unions or employers' associations. Changes in government policy that lead to a deviation of regulation from this level lead to an increasing loss in utility (for instance in the form of votes that can be obtained). This basically reflects the redistributive feature of labor market policy reforms where some groups in society gain and other lose. The influence of such particular interests is reflected in $c$ with a low $c$ denoting a government being more concerned with employment per se and a high $c$ reflecting a government under considerable pressure from societal groups.

The labor court's preferences are strongly influenced by the government's preferences.We assume an objective function (a loss function) for the labor

\footnotetext{
${ }^{4} \mathrm{~A}$ more eclectic view on the impact of various labor market institutions on labor market performance can be found in Freeman (2005), Nickell et al. (2005) or Blanchard (2006).

${ }^{5}$ One could allow for different ideological leanings of the government by assuming $\bar{\theta}_{i}$ with $i$ reflecting different types of governments. A left wing government would then have a higher $\bar{\theta}_{i}$ than a right wing government and vice versa.
} 
court given by

$$
V^{C}=u^{2}+b(e-\widehat{e})^{2}
$$

The labor court as well aims to avoid that unemployment deviates to much from the target level of zero, and that the realized level of its regulation decisions deviates too much from a target level $\widehat{e}=(1-\chi) \bar{e}+\chi \theta$, which is a weighted average of the court's own preferred level of regulation $\bar{e}$ and the government's policy decision $\theta$. A more pronounced conflict between the court and the government with respect to the "appropriate" level of labor market regulation is reflected in a lower $\chi$ and vice versa. The parameter $b>0$ weighs those two losses.

Thus, we think of judges as having policy preferences similar to those of legislators. Like legislators, they have well clearly defined preferences on policies, potentially shaped by their ideological stances. Judges and courts that are more labor friendly or are committed to left-leaning parties might prefer a high level of regulation, whereas more conservative or employer friendly judges might have low levels of $\bar{e}$. However, judges are rarely entirely free to set policies but are forced, at least to some degree, to take existing labor market regulation as a basis for their rulings. Thus, their target levels are also influenced by the government's decision $\theta$. For instance, judges may act in accordance with their preferred political parties in order to safeguard them from attacks from the opposition. Such a view on judges preferences finds widespread support in the law and economics literature on the behavioral foundations of judges (see Posner (2005)). ${ }^{6}$ Moreover recent empirical evidence on the behavior of labor courts finds, for instance, that judges act more employee friendly in depressed labor markets (Ichino et al. (2003)). Berger and Neugart (2006) show that German higher-level labor court judges follow ideological interests when adjudicating cases.

Moreover, the inclusion of a loss term for the deviation from the legal code set by the government in judges' utility functions has been argued for by Posner (1993). While a political judge may be able to deviate from the

\footnotetext{
${ }^{6}$ For example, Shepsle and Bonchek (1997) coin judges as "legislators in robes". A recent contribution analyzing consequences on the evolution of common law from politically motivated judges is Gennaioli and Shleifer (2007).
} 
existing legal code to express his own policy preferences, he will usually also incur costs from doing so. Reversal of a government decision may be costly in terms of his career concerns (see also Levy (2005)), and in any case a deviation from the legal code involves costly expression of a separate opinion. Furthermore, the judge may also be concerned about his reputation among other judges whose work he criticizes.

\subsection{Policy decisions}

As indicated above, we assume that the government is the Stackelberg-leader in this game between government and legal system. This assumption is justified by the fact that regulation policy set by the government is relatively infrequent whereas the actions of the court are more frequent.

Inserting equation (1) in the courts' objective function (3), we have the optimal level of regulation ruled by the court as

$$
e=\eta[b(1-\chi) \bar{e}-(1-b \chi) \theta-\widehat{u}]
$$

with $\eta=\frac{1}{1+b}$ as the court's reaction parameter. The court will set a more employment friendly regulation level the higher is the non-regulation level of unemployment $\widehat{u}$, and the higher is the level of regulation set by the government $\theta$. Thus, periods of crises and structural effects, like globalization, lead to more employment friendly policies because judges as well are assumed to aim for low unemployment. Not surprisingly, government regulation and court regulation are strategic substitutes, so that courts set a less aggressive regulation policy if the level of regulation set by the government is already high. Finally, regulation is increasing in the court's "target level of regulation" $\bar{e}$. The personal interest of the court (or its ideological preference for a certain level of regulation) $b$ clearly increases $e$. Whether $\theta$ or $\bar{e}$ dominates depends, of course, on $\chi$.

When determining the government's optimal policy, we have to take into account that the government has to set its policy under uncertainty, before the labor court rules on labor market policies. We assume that the court's action is not perfectly predictable due to the discretionary nature of the ju- 
dicial system. While there is a legal code, interpretation of the legal code is essentially done by the courts and thus $e$ may deviate from $\theta$. The more independent the legal system is, the more a court can follow its own convictions. Moreover, the government may not be perfectly informed about the leanings of the judiciary, perhaps simply due to the fact that court decisions are usually not taken by one single person but by a group of judges. If judges are appointed by different governments because spells on the bench overlap with governments' time in office, a particular government may not be able to predict individual preferences perfectly or not be able to predict the outcome of the interaction of judges with different preferences. That is, the reaction function of the court with respect to particular events may not be perfectly known, and we assume from the government's point of view that the court's reaction parameter $\eta$ is uncertain with $E(\eta)=\eta$ and $\operatorname{Var}(\eta)=\sigma_{\eta}^{2} \cdot{ }^{7}$

Taking this into account, the government's policy is

$$
\theta=\frac{c \bar{\theta}-\left(\eta^{2}+\sigma_{\eta}^{2}\right) b^{2}(1+\chi)[\widehat{u}+(1-\chi) \bar{e}]}{c+\eta^{2}+\sigma_{\eta}^{2}} .
$$

Comparative statics on the optimal policy of the government yield the following results:

- $\theta$ is decreasing in $\widehat{u}$ reflecting the fact that increases in trend unemployment will lead governments to pursue a less aggressive regulatory policy in order not to increase unemployment further.

- $\theta$ is decreasing in uncertainty $\sigma_{\eta}^{2}$, that is, the higher is the uncertainty about the court's behavior the lower is the level of regulation set by the government. If governments cannot fully control courts they are prompted to be less aggressive in their regulation policy.

- $\theta$ decreases more when $\widehat{u}$ increases if the uncertainty $\sigma_{\eta}^{2}$ about the court's behavior is larger. That is, uncertainty and trend unemployment are mutally reinforcing in their influence on government policy.

\footnotetext{
${ }^{7}$ That is, we assume that on average the government predicts $\eta$ correctly.
} 
- $\theta$ is increasing in $c$, the government's aversion to deviations from its preferred level of regulation. Obviously, the more important regulation is for the government, the more it will attempt to reach this preferred level.

- $\theta$ is decreasing in $\bar{e}$ reflecting the fact that the level of regulation set by the government and the preferred position of the court for worker friendly policy are substitutes.

- Finally, $\theta$ is decreasing in $b$ the relative weight that the court puts on reaching its preferred level of worker protection.

Using $\theta$ one can determine the equilibrium level of $e$ and then derive the equilibrium unemployment. Both solutions are not shown or discussed as our focus is on explaining labor market regulation.

\section{Evidence}

Next, we use panel data to test for the predictions of our model, particularly the effect of uncertainty of court behavior on governments' incentives to change labor market regulation. The data comprises 16 to 18 OECD countries (depending on the type of model that we estimate). ${ }^{8}$ As described below, our dependent variable is only available on a five year basis starting in 1970, so in order to have any meaningful time variation we only consider countries where we have at least five observations . Hence, our data set is unbalanced and consists of around 100 (again, depending on the model that is estimated) observations. We employ a generalized least square estimator taking into account heteroscedasticity of errors between countries and panel specific autocorrelation of errors. All regressions contain time and country fixed effects to control for variation that our other regressors might not capture.

\footnotetext{
${ }^{8}$ In model 1 as shown in table 2 the following countries are included: Austria, Belgium, Canada, Denmark, Finland, France, Germany, Greece, Italy, Japan, Netherlands, Norway, Portugal, Spain, Sweden, Switzerland, United Kingdom, United States.
} 
As a measure for labor market regulation we recur to a (sub)index of the Fraser Institute's Index of Economic Freedom. ${ }^{9}$ This index $(l m r)$ quantifies labor market regulations such as minimum wages, hiring and firing practices, the share of the labor force whose wages are set by centralized collective bargaining, and unemployment benefits (See table 1 for summary statistics for all variables that we use.) In principle this index may vary between 0 and 10. Our sample has a mean of 4.65 with the most regulated economy showing up with a value of 2.6 (the Netherlands in year 1970) and the least regulated being classified with 8.1 (Japan in year 1985).

Our model recurs to variation in structural unemployment as the source of crises to which governments and labor courts react in terms of regulation. Because we lack panel data for that variable, we make use of the misery index in our testing which uses the sum of the (logs of) the unemployment rate and the inflation rate. Based on the concept of a natural rate of unemployment, our misery index serves as a proxy for the structural unemployment rate. Deviations of the actual unemployment rate (which we measure) from a natural rate of unemployment are adjusted for by the inflation rate. According to the natural rate hypothesis changes in the actual unemployment rate that mirror a change in the underlying structural unemployment rate should not be accompanied by any variation in the inflation rate. Contrarily, if for example a drop in the unemployment rate did not reflect a shift in the structural rate of unemployment, inflation should have increased which would lead to a smaller (or no) change in the misery variable indicating that actual unemployment decreased but not the structural rate. The mean unemployment rate in our sample is $6 \%$. The inflation rate is averaging at $7 \%$. Both variables show considerable variation over time and countries and are negatively correlated.

The degree of uncertainty with which a government is confronted as courts decide is central to our story. We use legal origin as a proxy for that. The underlying assumption for using this indicator is that in a common law system where courts decide on a case basis outcomes of the legal system may

\footnotetext{
${ }^{9}$ In the Appendix we provide a detailed description of all variables and corresponding data sources.
} 
vary to a larger extent than in a civil law system which codifies (strict) rules that judges have to follow. The notion of legal origin defining the discretion of the judiciary system has gained considerable attention in the literature as a major cause for the proliferation of market regulation. See, e.g., La Porta et al. (1998), Djankov et al. (2002), Djankov et al. (2003), La Porta et al. (2004), and Botero et al. (2005). We give a twist to the existing studies by using this well know indicator as a proxy for uncertainty from the perspective of the government about how courts will handle labor market regulation. Principally, we use the same indicator which draws on the CIA's The World Factbook. The assertion made in those references whether a legal system has a common or a civil law origin refers to a country's legal system in general. However, as we deal with labor market regulation we adjusted the index in the case of Germany classifying it case-based as this is how legal scholars see German labor law (Richardi (2005)). We know of no other country in our sample where we should adjust the index. ${ }^{10}$ Note, that out of the 18 countries in our sample, four have a common (labor) law (Canada, Germany, United Kingdom, United States).

In order to control for other, possibly competing explanations of labor market regulation, we introduce a set of additional variables. One may argue that (labor market) policy change is hampered by veto players - in terms of their number or, given their number, the distance in their preferences over economic policies (Tsebelis (2002)). We try to model this potential explanation by using a five-year average of an indicator developed by Henisz (2000). This indicator (polcon) takes into account the number of veto players and their heterogeneity with respect to policies. It may vary between 0 and 1 with higher values indicating more resistance to policy changes. ${ }^{11}$ We interact polcon with lagged regulation $(\operatorname{lmr}(t-5)$.

Furthermore, one may be concerned that ideologies towards certain types of regulatory actions explain economic policy reform. In this case, simply the color of the ruling governments should have an impact on the policy. For this

\footnotetext{
${ }^{10}$ Note, however, that all the empirical results that we present below do not depend on Germany's classification of the legal system.

${ }^{11}$ The minimum of 0 refers to the dictatorships in Spain and Portugal that still existed in the earlier part of our sample period.
} 
we control with a dummy variable that is one (and otherwise zero) if within the last five years the executive stemmed from the left side of the political spectrum as defined by the World Bank Indicators on Political Institutions.

Finally, we take care of the potential influence interest groups may exert on labor market regulation. Here we opted for union density as a proxy for the influence for trade unions on (labor market) policies. The sample mean for union density is at roughly $40 \%$ of the workforce (ranging from $9 \%$ to $87 \%)$.

In table 2 we summarize our regression results. Model 1 presents the results when we simply regress labor market regulation on itself with a five year lag and the set of time and country fixed effects. The positive coefficient suggests a monotone convergence to some steady state level of labor market regulation. ${ }^{12}$ Extending this simple specification with the five years lagged value of our misery variable shows that countries in crisis tend to deregulate the labor market. Moreover our point estimate of 0.187 is highly significant. Introducing the interaction variable taking into account the uncertainty a government may face with respect to the actions of the labor courts yields the sign predicted by our model. In common law countries, for which we argue that governments face more uncertainty with respect to courts' behavior, governments deregulate more in response crises. The estimated parameter is significant at the $1 \%$ level. Furthermore, the parameter on the lagged misery variable hardly changes with the inclusion of the interaction term. Evaluated at the sample mean of the common variable a crisis of the size of one standard deviation increases labor market regulation by 0.25 units (in a sample size varying between 2.6 and 8.1). Almost a third of that effect is driven by the interaction term which captures the uncertainty that a government faces with respect to what the legal system will do.

Next, we turn to our additional control variables. We do not find evidence for the veto player story. The coefficient on the variable that interacts the measure for policy resistance with the lagged index of labor market regula-

\footnotetext{
${ }^{12}$ Note, however, that our estimates are subject to the Nickell bias as $N>T$. Thus, an interpretation of the size of the parameter with respect to the speed of the adjustment process would be misleading.
} 
tion is insignificant. Perhaps more importantly the inclusion of the lagged interaction variable on policy resistance does also not harm our findings that uncertainty of court rulings spurs governments' incentives to deregulate in times of crises. The lagged labor market regulation variable loses some of its precision. In Model 5 and Model 6 we control for the political color of the executive and the potential role of interest groups, respectively. Neither do governments on the left of the political spectrum conduct labor market policies differently from governments of the other political color, nor do unions have an influence on labor market regulations in our sample. It is still crises which coincides with lower labor market regulation, and the more so as the courts' rulings are uncertain from the perspective of the policy making institution. Note that the inclusion of those additional two controls renders the lagged labor market regulation index insignificant.

In Model 3, which is our most preferred specification, all country fixed effects except for one show up significantly. In addition, all time fixed effects are significant. Overall, most of those fixed effects are significant at a onepercent significance level. Figure 2 contrasts the predicted labor market regulations of our model against the actual values.

Overall, we are quite satisfied with our empirical findings. A check for robustness of Model 3 where we excluded countries sequentially from our sample was rather promising. Only in two cases (Canada and Japan) the parameter on the misery variable became insignificant. ${ }^{13}$ One may raise concerns about the validity of our endogenous variable as the Fraser Institute is mostly considered as liberal perhaps biasing the labor market regulation index. Firstly, such a bias will not affect our results as long as it leads to an exaggerated description of the extent of labor market regulation throughout the panel. Secondly, the Global Labor Survey, an internet based survey among labor practitioners including union leaders, activists or professor for labor law revealed that the index by the Fraser Institute (which we use) gives a similar picture as the Global Labor Survey Chor and Freeman (2005). The

\footnotetext{
${ }^{13}$ Note, however, that our results react sensitively to the inclusion of New Zealand in our sample. For Model 3 the parameters on misery $(t-5)$ and the interacted misery variable become insignificant with p-values slightly above the $10 \%$ margin.
} 
Table 1: Summary statistics

\begin{tabular}{lcccc}
\hline Variable & Mean & Std. Dev. & Min. & Max. \\
\hline $\operatorname{lmr}$ & 4.65 & 1.522 & 2.6 & 8.1 \\
ur & 5.985 & 4.05 & 0.2 & 22.7 \\
inflation & 6.995 & 5.537 & -0.671 & 24.875 \\
misery & 3.221 & 1.052 & -0.218 & 5.221 \\
exe_left & 0.159 & 0.367 & 0 & 1 \\
union & 0.418 & 0.2 & 0.09 & 0.87 \\
polcon & 0.734 & 0.186 & 0 & 0.893 \\
common & 0.222 & 0.417 & 0 & 1 \\
\hline
\end{tabular}

advantage of the Fraser Institute is its time dimension which gives us an additional source of variation. 


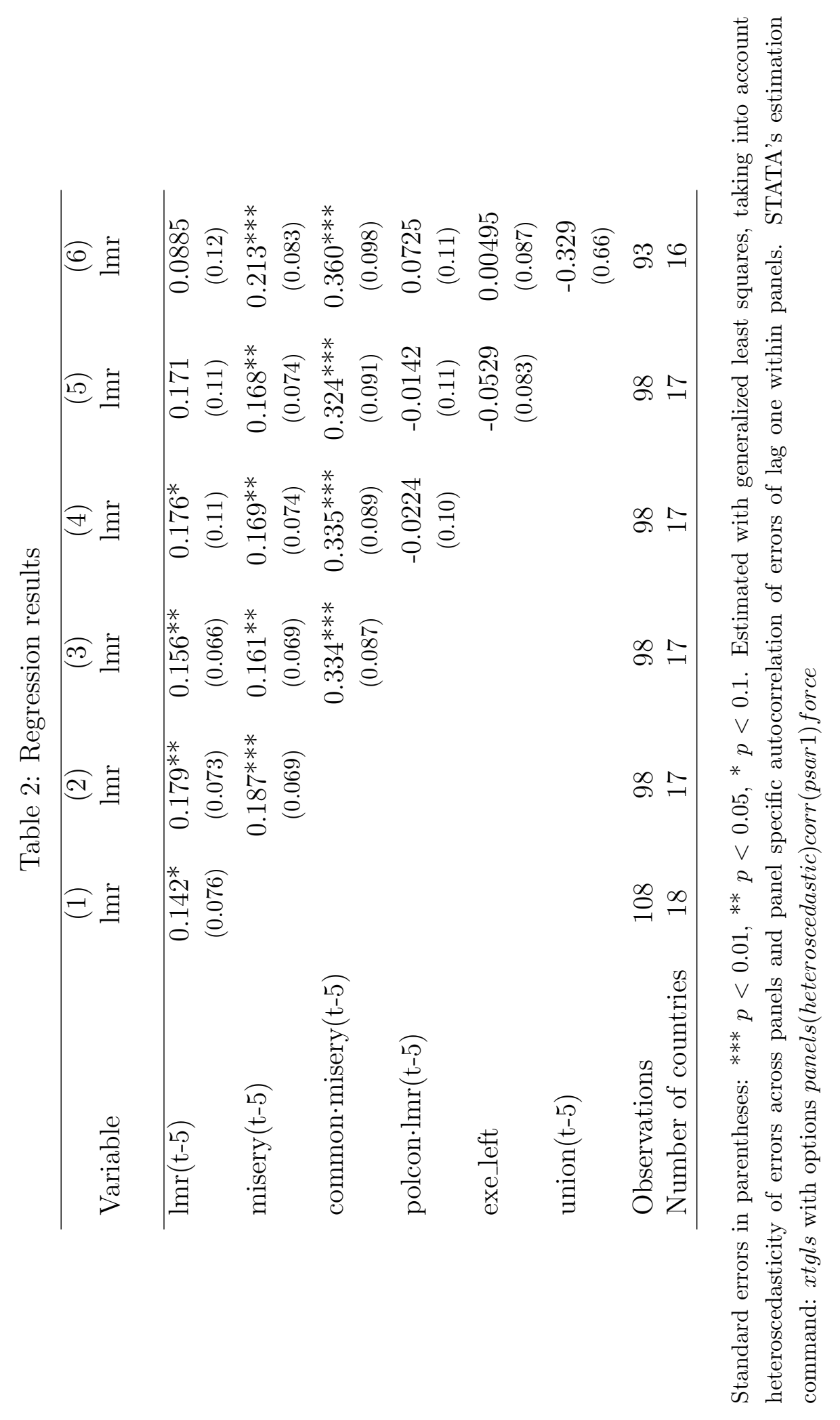




\section{Conclusions}

In this paper, we look at the issue of labor market policy regulation. Our approach differs from the existing literature in that we explicitly take into account labor courts as a strategic player. We believe that the role of courts has so far been largely neglected in studying governments' incentives for policy change. This is problematic, given the ample evidence concerning the discretion that courts have in interpreting the legal code. Our main finding is that as labor courts' actions are more uncertain from the perspective of the government, governments will reform more intensively. The more discretion labor courts have, the more governments have an incentive to pursue employment friendly regulatory policy. In addition to the formal derivation of this result, we also present evidence to support this finding. Taking the legal origin of countries as a proxy for judiciary discretion, and thus uncertainty about labor courts' actions, we find that governments' policies differ significantly in response to crises. Countries with a civil law origin respond less to economic crisis than countries with a common law system.

While we stress the interaction between governments enacting labor market regulation and labor courts activity, there are certainly other fields of economic policy making where this type of interaction between governments and the legal system could play an important role in explaining policy making. There is, for instance, also still little knowledge about economic policy making in the context of a European legal system, an issue which is becoming more and more important for national policymakers.

\section{Appendix}

\section{Data sources}

In the following we summarize the definitions of the variables used in the regression models and the data sources.

- Imr: Labor market regulation as measured by the Fraser Institute's Index of Economic Freedom, Area 5B. This comprises information on 
labor market regulations such as minimum wages, hiring and firing practices, the share of the labor force whose wages are set by centralized collective bargaining and unemployment benefits system. The index may vary between 0 and 10 with higher values indicating a less regulated economy. Source: Economic Freedom of the World, 2005 Annual Report by J. Gwartney, R. Lawson and E. Gartzke.

- misery: This variable is the sum of the logs of the unemployment rate $u r$ and the inflation rate inflation in a respective country at time $t$ as an average of the past five years. The inflation rate is based on consumer prices. The unemployment rate corresponds to the OECD's definition of standardized unemployment rates. Source: World Development Indicators (http : //web.worldbank.org) and OECD (http : //www1.oecd.org/scripts /cde/members/lf sindicatorsAuthenticate.asp)

- common: This is a dummy variable with the value of 1 for all countries classified as having a common law origin. The variable is zero for all other cases. Legal origin is defined as in Botero et al. (2005). Source: http : //mba.tuck.dartmouth.edu/pages/faculty/rafael.laporta/ publications.html and CIA World Factbook 2007, https ://www.cia.gov/cia/publications/factbook/.

- exe_left: This variable is based on data provided by the World Bank Indicators on Political Institutions. The variable execrlc is recoded as a dummy variable such that it is one if the party affiliation of the executive is left AND the executive did not change color within the last five years. Source: DPI2004 Database of Political Institutions: Changes and Variable Definitions, by P. Keefer, July 2005 (http : //econ.worldbank.org).

- union: Union density as a five year average of yearly values. The values for the years 1996-2000 are averages of the years 1996 to 1998. Source: LMIDB Version 2.0, Nickell and Nunziata (2001). 
- polcon: This variable captures the feasibility of policy change. It ranges from 0 to 1 . At time $t$ values are stored which are averages of $P O L$ $C O N V$ of the five past years. POLCONV basically reflects the number of independent branches of governments that have veto power, their preferences, the status quo policy, and heterogeneity between and of veto players. Source: Henisz (2000). 


\section{References}

Alesina, A. And A. Drazen (1991): "Why are stabilizations delayed?" American Economic Review, 81, 1170-1188.

Autor, D. (2003): "Outsourcing at will: the contribution of unjust dismissal doctrine to the growth of employment outsourcing," Journal of Labor Economics, 21, 1-42.

Berger, H. And S. Danninger (2006): "Does excessive regulation impede growth in Germany?" IMF Country Report 06/17, 106-133.

Berger, H. and M. Neugart (2006): "Labor courts, nomination bias, and unemployment in Germany," CESifo Working Paper No. 1752, revised version.

Blanchard, O. (2006): "European unemployment: The evolution of facts and ideas," Economic Policy, 21, 5-60.

Botero, J., S. Djankov, R. La Porta, F. Lopez-De-Silanes, And A. ShleIfer (2005): "The regulation of labor," Quarterly Journal of Economics, 119, 1339-1382.

Calmfors, L. (2001): "Labor market reform and monetary union," Journal of Labor Economics, 19, 265-289.

Chor, D. And R. Freeman (2005): "The 2004 Global Labor Survey: Workplace Institutions and Practices Around the World," NBER Working Paper No. 11598.

Djankov, S., R. La Porta, F. Lopez-De-Silanes, and A. Shleifer (2002): "The regulation of entry," Quarterly Journal of Economics, 117, $1-38$.

(2003): “Courts," Quarterly Journal of Economics, 118, 453-518.

Drazen, A. (2000): Political Economy in Macroeconomics, Princeton: Princeton University Press. 
Fernandez, R. And D. Rodrik (1991): "Resistance to reform: status quo bias in the presence of individual-specific uncertainty," American Economic Review, 81, 1146-1155.

Freeman, R. (2005): "Labour market institutions without blinders: the debate over flexibility and labour market performance," NBER Working Paper 11286.

Gennaioli, N. And A. Shleifer (2007): "The evolution of common law," Journal of Political Economy, 115, 43-68.

GrüneR, H. P. (2002): "Unemployment and labor-market reform: a contract theoretic approach," Scandinavian Journal of Economics, 104, 641656.

Hefeker, C. (2001): "Labor market rigidities and EMU," Journal of Economic Integration, 16, 229-244.

- (2006): "EMU enlargement, policy uncertainty and economic reforms," CESifo Working Paper No. 1767.

Henisz, W . (2000): "The institutional environment for growth," Economics and Politics, 12, 1-31.

Ichino, A., M. Polo, And E. Rettore (2003): "Are judges biased by labor market conditions?" European Economic Review, 47, 913-944.

La Porta, R., F. Lopez-De-Silanes, C. Pop-Eleches, And A. Shleifer (2004): "Judicial checks and balances," Journal of Political Economy, 112, 445-470.

La Porta, R., F. Lopez-De-Silanes, A. Shleifer, and R. Vishny (1998): "Law and finance," Journal of Political Economy, 106, 1113-1155.

LEvy, G. (2005): "Careerist judges and the appeals process," RAND Journal of Economics, 36, 275-297. 
Neugart, M. (2002): "Interest groups, enlargement of the EMU and labor market reform," in Institutional Conflicts and Complementarities - Monetary Policy and Wage Bargaining Institutions in EMU, ed. by R. Franzese, P. Mooslechner, and M. Schürz, Dordrecht: Kluwer, 147-164.

NiCkell, S. AND L. Nunziata (2001): "Labour market institutions database," September 21, 2001.

Nickell, S., L. Nunziata, And W. Ochel (2005): "Unemployment in the OECD since the 1960s: what do we know?" The Economic Journal, $115,1-27$.

OECD (1994): The OECD Jobs Study.

\section{- (2004): OECD Employment Outlook.}

Olson, M. (1965): The Logic of Collective Action: Public Goods and the Theory of Groups, Cambridge: Harvard University Press.

Posner, R. A. (1993): "What do judges and justices maximize? (The same thing as everybody else)," Supreme Court Economic Review, 3, 1-41.

- (2005): "Judicial behavior and performance: an economic approach," Florida State University Law Review, 32, 1259-1279.

RICHARDI, R. (2005): "Arbeitsverfassung/Arbeitsrecht," in Geschichte der Sozialpolitik in Deutschland seit 1945, Nomos, various Volumes, in print.

Roland, G. (2002): "The political economy of transition," Journal of Economic Perspectives, 16, 29-50.

Saint-Paul, G. (2000): The Political Economy of Labour Market Institutions, Oxford: Oxford University Press.

Shepsle, K. A. And M. S. BoncheK (1997): Analyzing Politics - Rationality, Behavior, and Institutions, New York: Norton.

Sibert, A. And A. Sutherland (2000): "Monetary regimes and labour markt reform," Journal of International Economics, 51, 421-435. 
Tsebelis, G. (2002): Veto players, Princeton University Press.

von Mehren, A. And J. Gordley (1957): The Civil Law System, An Introduction to the Comparative Study of Law, Boston: Little, Brown and Company. 
HIN:

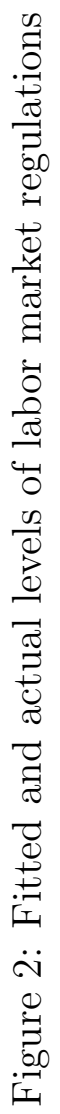

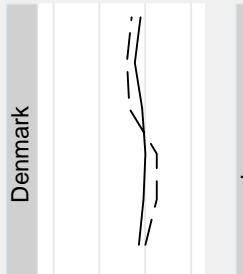

if

का

$\mid$

)

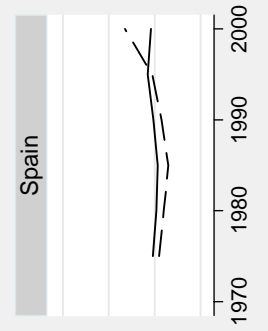

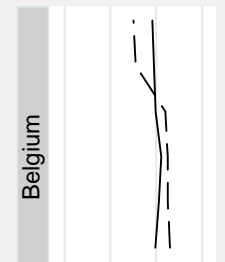

$\mid$

if

$\mid$

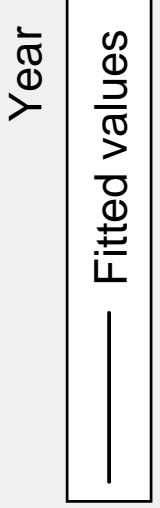
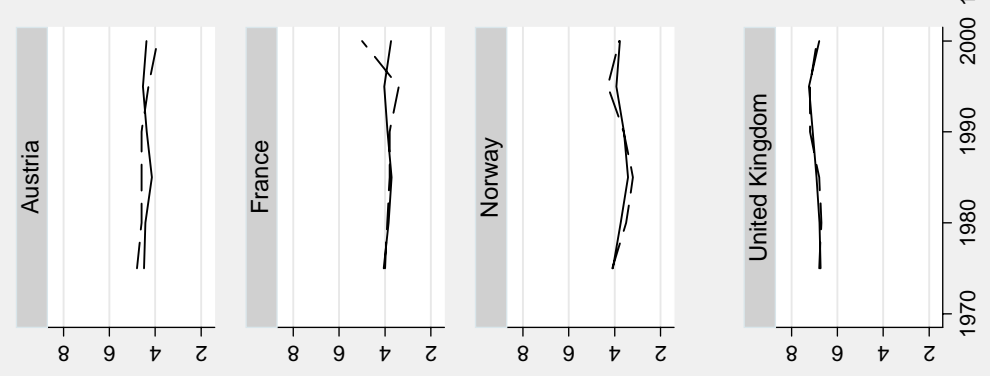

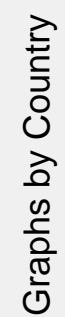




\section{CESifo Working Paper Series}

(for full list see www.cesifo-group.de)

1976 Andreas Haufler and Ian Wooton, Competition for Firms in an Oligopolistic Industry: Do Firms or Countries Have to Pay?, April 2007

1977 Eckhard Janeba, Exports, Unemployment and the Welfare State, April 2007

1978 Gernot Doppelhofer and Melvyn Weeks, Jointness of Growth Determinants, April 2007

1979 Edith Sand and Assaf Razin, The Role of Immigration in Sustaining the Social Security System: A Political Economy Approach, April 2007

1980 Marco Pagano and Giovanni Immordino, Optimal Regulation of Auditing, May 2007

1981 Ludger Woessmann, Fundamental Determinants of School Efficiency and Equity: German States as a Microcosm for OECD Countries, May 2007

1982 Bas Jacobs, Real Options and Human Capital Investment, May 2007

1983 Steinar Holden and Fredrik Wulfsberg, Are Real Wages Rigid Downwards?, May 2007

1984 Cheng Hsiao, M. Hashem Pesaran and Andreas Pick, Diagnostic Tests of Cross Section Independence for Nonlinear Panel Data Models, May 2007

1985 Luis Otávio Façanha and Marcelo Resende, Hierarchical Structure in Brazilian Industrial Firms: An Econometric Study, May 2007

1986 Ondřej Schneider, The EU Budget Dispute - A Blessing in Disguise?, May2007

1987 Sascha O. Becker and Ludger Woessmann, Was Weber Wrong? A Human Capital Theory of Protestant Economic History, May 2007

1988 Erkki Koskela and Rune Stenbacka, Equilibrium Unemployment with Outsourcing and Wage Solidarity under Labour Market Imperfections, May 2007

1989 Guglielmo Maria Caporale, Juncal Cunado and Luis A. Gil-Alana, Deterministic versus Stochastic Seasonal Fractional Integration and Structural Breaks, May 2007

1990 Cláudia Costa Storti and Paul De Grauwe, Globalization and the Price Decline of Illicit Drugs, May 2007

1991 Thomas Eichner and Ruediger Pethig, Pricing the Ecosystem and Taxing Ecosystem Services: A General Equilibrium Approach, May 2007

1992 Wladimir Raymond, Pierre Mohnen, Franz Palm and Sybrand Schim van der Loeff, The Behavior of the Maximum Likelihood Estimator of Dynamic Panel Data Sample Selection Models, May 2007 
1993 Fahad Khalil, Jacques Lawarrée and Sungho Yun, Bribery vs. Extortion: Allowing the Lesser of two Evils, May 2007

1994 Thorvaldur Gylfason, The International Economics of Natural Resources and Growth, May 2007

1995 Catherine Roux and Thomas von Ungern-Sternberg, Leniency Programs in a Multimarket Setting: Amnesty Plus and Penalty Plus, May 2007

1996 J. Atsu Amegashie, Bazoumana Ouattara and Eric Strobl, Moral Hazard and the Composition of Transfers: Theory with an Application to Foreign Aid, May 2007

1997 Wolfgang Buchholz and Wolfgang Peters, Equal Sacrifice and Fair Burden Sharing in a Public Goods Economy, May 2007

1998 Robert S. Chirinko and Debdulal Mallick, The Fisher/Cobb-Douglas Paradox, Factor Shares, and Cointegration, May 2007

1999 Petra M. Geraats, Political Pressures and Monetary Mystique, May 2007

2000 Hartmut Egger and Udo Kreickemeier, Firm Heterogeneity and the Labour Market Effects of Trade Liberalisation, May 2007

2001 Andreas Freytag and Friedrich Schneider, Monetary Commitment, Institutional Constraints and Inflation: Empirical Evidence for OECD Countries since the 1970s, May 2007

2002 Niclas Berggren, Henrik Jordahl and Panu Poutvaara, The Looks of a Winner: Beauty, Gender, and Electoral Success, May 2007

2003 Tomer Blumkin, Yoram Margalioth and Efraim Sadka, Incorporating Affirmative Action into the Welfare State, May 2007

2004 Harrie A. A. Verbon, Migrating Football Players, Transfer Fees and Migration Controls, May 2007

2005 Helmuth Cremer, Jean-Marie Lozachmeur and Pierre Pestieau, Income Taxation of Couples and the Tax Unit Choice, May 2007

2006 Michele Moretto and Paolo M. Panteghini, Preemption, Start-Up Decisions and the Firms' Capital Structure, May 2007

2007 Andreas Schäfer and Thomas M. Steger, Macroeconomic Consequences of Distributional Conflicts, May 2007

2008 Mikael Priks, Judiciaries in Corrupt Societies, June 2007

2009 Steinar Holden and Fredrik Wulfsberg, Downward Nominal Wage Rigidity in the OECD, June 2007 
2010 Emmanuel Dhyne, Catherine Fuss, Hashem Pesaran and Patrick Sevestre, Lumpy Price Adjustments: A Microeconometric Analysis, June 2007

2011 Paul Belleflamme and Eric Toulemonde, Negative Intra-Group Externalities in TwoSided Markets, June 2007

2012 Carlos Alós-Ferrer, Georg Kirchsteiger and Markus Walzl, On the Evolution of Market Institutions: The Platform Design Paradox, June 2007

2013 Axel Dreher and Martin Gassebner, Greasing the Wheels of Entrepreneurship? The Impact of Regulations and Corruption on Firm Entry, June 2007

2014 Dominique Demougin and Claude Fluet, Rules of Proof, Courts, and Incentives, June 2007

2015 Stefan Lachenmaier and Horst Rottmann, Effects of Innovation on Employment: A Dynamic Panel Analysis, June 2007

2016 Torsten Persson and Guido Tabellini, The Growth Effect of Democracy: Is it Heterogenous and how can it be Estimated?, June 2007

2017 Lorenz Blume, Jens Müller, Stefan Voigt and Carsten Wolf, The Economic Effects of Constitutions: Replicating - and Extending - Persson and Tabellini, June 2007

2018 Hartmut Egger and Gabriel Felbermayr, Endogenous Skill Formation and the Source Country Effects of International Labor Market Integration, June 2007

2019 Bruno Frey, Overprotected Politicians, June 2007

2020 Jan Thomas Martini, Rainer Niemann and Dirk Simons, Transfer Pricing or Formula Apportionment? Tax-Induced Distortions of Multinationals' Investment and Production Decisions, June 2007

2021 Andreas Bühn, Alexander Karmann and Friedrich Schneider, Size and Development of the Shadow Economy and of Do-it-yourself Activities in Germany, June 2007

2022 Michael Rauscher and Edward B. Barbier, Biodiversity and Geography, June 2007

2023 Gunther Schnabl, Exchange Rate Volatility and Growth in Emerging Europe and East Asia, June 2007

2024 Erkki Koskela and Ronnie Schöb, Tax Progression under Collective Wage Bargaining and Individual Effort Determination, June 2007

2025 Jay Pil Choi and Marcel Thum, The Economics of Politically Connected Firms, June 2007

2026 Jukka Pirttilä and Roope Uusitalo, Leaky Bucket in the Real World: Estimating Inequality Aversion Using Survey Data, June 2007 
2027 Ruslan Lukach, Peter M. Kort and Joseph Plasmans, Strategic R\&D with Knowledge Spillovers and Endogenous Time to Complete, June 2007

2028 Jarko Fidrmuc, Neil Foster and Johann Scharler, Labour Market Rigidities, Financial Integration and International Risk Sharing in the OECD, June 2007

2029 Bernardina Algieri and Thierry Bracke, Patterns of Current Account Adjustment Insights from Past Experience, June 2007

2030 Robert Dur and Hein Roelfsema, Social Exchange and Common Agency in Organizations, June 2007

2031 Alexander Libman and Lars P. Feld, Strategic Tax Collection and Fiscal Decentralisation: The Case of Russia, June 2007

2032 Øystein Foros, Hans Jarle Kind and Greg Shaffer, Resale Price Maintenance and Restrictions on Dominant Firm and Industry-Wide Adoption, June 2007

2033 Jan K. Brueckner and Kurt Van Dender, Atomistic Congestion Tolls at Concentrated Airports? Seeking a Unified View in the Internalization Debate, June 2007

2034 Viet Do and Ngo Van Long, International Outsourcing under Monopolistic Competition: Winners and Losers, June 2007

2035 Nadia Fiorino and Roberto Ricciuti, Determinants of Direct Democracy, June 2007

2036 Burkhard Heer and Alfred Maussner, Inflation and Output Dynamics in a Model with Labor Market Search and Capital Accumulation, June 2007

2037 Konstantinos Angelopoulos, Jim Malley and Apostolis Philippopoulos, Public Education Expenditure, Growth and Welfare, June 2007

2038 Maarten Bosker, Steven Brakman, Harry Garretsen and Marc Schramm, Adding Geography to the New Economic Geography, June 2007

2039 Steffen Henzel, Oliver Hülsewig, Eric Mayer and Timo Wollmershäuser, The Price Puzzle Revisited: Can the Cost Channel Explain a Rise in Inflation after a Monetary Policy Shock?, July 2007

2040 Rosario Crinò, Service Offshoring and White-Collar Employment, July 2007

2041 Carsten Hefeker and Michael Neugart, Labor Market Regulation and the Legal System, July 2007 